\title{
Predictors of Fear and Risk of Terrorism in a Rural State*
}

\author{
David C. May ${ }^{1}$, Joe Herbert ${ }^{2}$, Kelly Cline ${ }^{1}$, and Ashley Nellis ${ }^{3}$ \\ ${ }^{1}$ Department of Criminal Justice \\ Eastern Kentucky University \\ 521 Lancaster Avenue, Stratton 467 \\ Richmond, KY 40475 \\ ${ }^{2}$ Department of Safety, Security, and Emergency Management \\ Eastern Kentucky University
}

521 Lancaster Avenue; Stratton 205

Richmond, KY 40475-3102

${ }^{3}$ The Sentencing Project

1705 DeSales Street, NW- 8th Floor

Washington, DC 20036

Contact author - David May: david.may@eku.edu; 0108596226681

\begin{abstract}
This article examines attitudes about terrorism utilizing criminological literature about fear of crime and perceived risk of victimization and data from a statewide survey of 1,617 adults in Kentucky. Measures of both fear of terrorism and perceived risk of terrorism were geography based. The demographic variables had minimal impact on both perceived risk of terrorism and fear of terrorism, although gender was significantly related to both, suggesting a link based on socialization experiences of men and women. Although rural residence had a small but statistically significant relationship to perceived risk, it was not related to fear. The strongest predictor of fear was perceived risk itself, which mirrors research on the close association of fear of crime and perceived risk to victimization.
\end{abstract}

\section{Keywords: Terrorism, Fear of Crime, Perceived Risk}

*Data used in this study were collected as part of a victimization survey funded by the Kentucky Statistical Analysis Center in March, 2008. Any opinions expressed in this study are those of the authors and not of the Kentucky Justice Cabinet or the Kentucky Statistical Analysis Center. 


\section{Introduction}

On September 11, 2001, 2,752 people lost their life in the attacks on the World Trade Center in New York (Hirschkorn 2007). That single event (perhaps more than any individual event since the bombing of Pearl Harbor in 1941) reshaped the mindset of both American citizens and American legislators. This terroristic event triggered a war on two fronts (Afghanistan and eventually Iraq), created a number of legislative acts and security procedures that reshaped public behavior throughout the United States, and, arguably, introduced a realization for many Americans that they were not as safe in their daily lives in the United States as they thought they were prior to 9/11. Nevertheless, despite these widespread changes, and despite anecdotal evidence that suggests Americans are more fearful of terrorism after 9/11 than they were prior to its occurrence, little scientific literature of which we are aware examines either the prevalence of fear of terrorism or the perceived likelihood of victimization by terrorism. Furthermore, practically none examines those perceptions among rural Americans.

In this article, we attempt to fill that gap in the literature by using data from over 1,600 adult Kentuckians to examine both their perceived risk of terrorism victimization and their fear of terrorism. By doing so, we hope to determine if (a) terrorism risk and fear of victimization are more pervasive than risk and fear of victimization by other types of crime; and (b) if the predictors of elevated perceptions of risk and fear of terrorism match those that we know predict perceived risk and fear of crime for other types of crime. By doing so, we hope to provide some understanding regarding the fear and risk of terrorism in rural communities.

\section{Definition of Terrorism}

The United States Federal Code defines terrorism as, "premeditated, politically motivated violence perpetrated against noncombatant targets by subnational groups or clandestine agents" (United States Federal Code, 2009, Title 22, Chapter 38, Para. 2656, section f2). However, this is only one of hundreds of definitions of terrorism; as such, despite the fact that most scholars agree that terrorism exists, not many can agree on the definition of terrorism. Kushner (2003) states that most definitions of terrorism hinge on one of three factors: the purpose, the target, and the method. In other words, most definitions of terrorism suggest that, in some form, terrorism is an act designed to instill fear through some form of violence that is politically motivated (Kushner 2003).

Terrorism can be domestic or international. Domestic terrorism is the act of violence primarily within the United States while international terrorism refers to the activities that involve violent acts that would be considered criminal if committed 
within the jurisdiction of the United States (National Victim Assistance Academy 2002). Given these components of the definition, terrorism is not only physical violence, but emotional violence as well. Because there is no single definition of terrorism, each person or country can hold its own definitions based on their political or religious orientation.

Terror is a device to control society by means of preventive intimidation under conditions of mass hysteria (Vasilenko 2004). In fact, Vasilenko (2004: 46) argues that the word "terror" is of Latin origin and can be translated to mean "fear" or "horror." Although terrorism is considered to be one of the most significant social problems confronting the world community in the $21^{\text {st }}$ century (Vasilenko 2004), some scholars suggest that before $9 / 11$, there was no nationwide fear of terrorism in the United States (Victor 2006).

In recent years, the United States has been subject to a number of terrorist attacks, including the first bombing of the World Trade Center in 1993; attacks on the USS Cole in 2000; and the aforementioned devastating attacks of September 11, 2001. Nevertheless, the events of $9 / 11$ brought about a dramatic change. Victor (2006) reported that in a Gallup Poll conducted in August, 2004, those surveyed were asked if they believed, "terrorists would target an attack against New York City and other big cities, or any place in the U.S." The majority of respondents (61 percent) stated they felt an attack could occur in any area of the United States while 31 percent reported that an attack could occur in New York City or bigger cities. In the same article, a national Gallup poll found that 41 percent of Americans said they were very worried or somewhat worried that they or someone in their family would become a victim of terrorism.

Since September 11, 2001, the media coverage of terrorist threats and terrorist groups has increased dramatically. DiMaggio (2008) claims that citizen fears are often driven by media framing of issues; when the media has a vested interest in an issue (e.g., terrorism), the reporting of that issue often becomes slanted so that the factual information is reported through a lens of fear and anxiety. Thus, the constant media attention to terrorism, its causes, and its consequences may undermine the larger social order by impacting psychological processes of citizens in the countries where terrorism is reported as a threat (Fisher, Greitemeyer, Kastenmuller, Frey, \& Oßwald 2007).

Fear is a powerful response to terrorism that may be distorted through media images and messages (Borgeson \& Valeri 2009). Compared to 20 or 30 years ago, advances in technology today are a leading contributor to the distribution of information to the public, and therefore, those distorted images. Local and national news media utilize the television, radio, and Internet as broadcasting tools to convey 
information to citizens in our fast-paced society. The language used by these media appears to be particularly troubling for certain demographic groups, as it has been shown to evoke fear in elderly citizens who live in rural areas at greater levels than those who live in larger cities, making older persons in rural localities more fearful of violent events and terrorist attacks than older persons in bigger places (Victor 2006).

As with other dramatic events, the media also exaggerates terrorism, in turn creating the potential to inflate the public's fear of terrorism and perceived risk of future attacks (Borgeson \& Valeri 2009). The authors go even further to acknowledge that the media's treatment of crime is much like that of its treatment of terrorism. In addition, they point to the fact that viewers reporting their main source of information as local news are more fearful of crime than those that report the national news as their main source of information. As such, fear of terrorism can be a by-product used by terrorist groups in an effort to disrupt society.

Josiger (2009) stated that "terrorism is a form of psychological warfare designed to maximize publicity and influence audiences significantly larger than the immediate victims (p. 4)." Josiger argues that the aim of terrorist attacks is to intimidate the targeted population and suggests that terrorists anticipate that the increased level of fear and political disaffection will force governments to make compromises that will ultimately make their attempts more successful. Therefore, the perceptions of the public are important in simultaneously driving the government's response to terrorism. In considering public perceptions in relation to counter-terrorism policies, the targeted governments that are unable of responding to terrorist acts will lose the support of the public; likewise, a government that reacts outrageously or restricts the public will be criticized.

Empirical evidence so far suggests that, despite the fact that several years have passed since 9/11, public fear of terrorism is still elevated (Nellis 2007). Some authors suggest that the public overestimates the threat of terrorist attacks (Friedman 2005) and that perceived risks are out of sync with reality. In fact, some authors suggest that American citizens have overestimated the threat of terrorist attacks given the decline of such attacks after September 11, 2001 (Friedman 2005) and argue that Americans are more likely to be struck by lightning or die in a car accident than to die in a terrorist attack.

Despite the evidence that suggests that terrorism negatively impacts the psyche of citizens in countries where terrorist attacks occur, and given that one of the goals of terrorist actions is to increase fear and concern about future terrorist activity, relatively few studies have examined fear of terrorism and its correlates. Those that do are discussed in detail below. 


\section{Fear of Terrorism}

After the terrorist attacks on September 11, 2001, Boscarino, Figley, and Adams (2003) addressed terrorism and the fear of terrorism using data collected from a sample of adults in the state of New York in September 2002. The state was divided into five regions: New York City, Long Island, Hudson Valley region, Upstate Eastern region, and Upstate Western region. Respondents were asked about their levels of concern (very concerned, somewhat concerned, not too concerned, not concerned at all) related to the following events happening in New York: (a) another major terrorist attack, (b) a terrorist attack involving biological weapons, such as smallpox or anthrax, and (c) a terrorist attack involving a "nuclear device" (p. 201).

Boscarino et al. (2003) found that almost half (45.7\%) of New Yorkers reported being "very concerned" about another major attack, 50.4 percent were very concerned about biological attacks, and 42.5 percent reported being very concerned about nuclear attacks. Additionally, one in three respondents (33.4\%) reported that they were very concerned about all three events occurring. Their multivariate analyses determined that women, older respondents, African Americans, Hispanics, and less educated respondents were all more fearful of terrorism than their counterparts. The downstate residents also reported higher levels of fear, as 41.7 percent of downstate respondents were very concerned about a major attack compared to only 22 percent for upstate respondents. Also, New York City and Long Island residents reported a higher level of concern and were more likely to report that they would evacuate immediately following another attack. The authors closed by stating that, overall, "there was a significant public concern about future terrorist attacks in New York (Boxcarino et al 2003: 203)."

Boscarino et al. (2003) made a significant contribution to the research in the area of fear of terrorism. Nevertheless, their research was the exception, not the rule. The other research that examines fear of terrorism is largely descriptive research and most of that research is conducted by the Gallup organization. In one Gallup poll, the questioned was posed, "How worried are you that you or someone in your family will become a victim of terrorism - very worried, somewhat worried, not too worried, or not worried at all (p. 128)?" The data collected since 1995 concluded that after the Oklahoma City bombing, 42 percent were somewhat or very worried. Before September 11, 2001, only 24 percent were somewhat worried; the day of 9/11, 35 percent were somewhat worried, while 24 percent were very worried (p. 128).

A second Gallup poll found that almost 9 in 10 Americans felt it was likely that bombings or similar acts of violence would occur elsewhere in the United States in the near future (Carroll 2009). In another Gallup poll, Carlson (2004) indicated that the public's concern regarding terrorism has declined since the September 11 terror 
attack; however, immediately following the attacks, more than half of Americans expressed concern about being victimized by another act of terrorism. Women were more worried about terrorism than men $(38 \%$ v $29 \%)$ but another variable of interest, political affiliation, did not impact one's fear of terrorism. Republicans, Democrats, and political independents were all equally likely to indicate they were very worried or somewhat worried about terrorism.

In a telephone interview of randomly selected national sample of 1,031 adults, Moore (1999) determined that there was little difference by age, gender, education, or partisan political orientation; however, individuals with higher incomes were less likely than those with lower incomes to report a fear of terrorist attacks. Moore found that, even before 9/11, 58 percent of respondents with a household income of less than $\$ 50,000$ per year reported they were less likely to attend a large public event on New Year's Day. Saad (2004) determined that although fear of terrorism has declined since the 9/11 events, fear of terrorism remained higher than pre-9/11 levels.

In sum, then, available evidence suggests that many Americans are fearful of terrorism and that fear of terrorism has detrimental impacts on their daily lives. Interestingly, none of the studies reviewed above compared predictors of fear of terrorism and perceived risk of terrorism to individuals' fear and perceived risk of victimization of more "traditional" crimes (e.g., robbery, theft, rape). Consequently, this relationship remains unexplored. In the following section, we provide a short summary and review of the available evidence regarding fear of crime, risk of criminal victimization, and its predictors. We then move to the purpose of this study and the relationship between fear and perceived risk of terrorism and fear and perceived risk of more traditional crimes.

\section{Predictors of Fear of Crime}

Although relatively few studies have explicitly examined fear of terrorism, intuitively, predictors of fear of terrorism should be similar to predictors of fear of other crimes as well. In the following pages, we review the available evidence regarding predictors of fear of crime and close by offering hypotheses (based on this literature) regarding how these demographic predictors should impact fear of terrorism.

There are a number of demographic factors that have demonstrated an association with fear of criminal victimization, including gender, age, race, income status, victimization status, and environmental context. For example, gender is a strong

predictor of fear of crime, with women expressing more fear of crime than men even though they are less likely to be victimized by crime in general than males. This 
discrepancy between fear levels and actual victimization rates is often called the "gender-fear paradox."

Several explanations are posed for this paradox, including suggestions that (1) women feel physically vulnerable because of their generally smaller physical stature than males; (2) women's fear of rape and violence from their spouses / partners / boyfriends "shadows" their fear of all other crimes (in other words, women associate rape with burglary, robbery and all other personal crimes, thus increasing their fear of those crimes because they fear they may be raped during that victimization experience, and (3) women's fear of crime and men's lack of fear of crime is part of the gender socialization process (Ferarro 1995; Ferraro 1996; Fisher \& Sloan 2003; Gilchrist et al. 1998; Goodey 1997; Haynie 1998; Killias \& Clerici 2000; May 2001a; May 2001b; Smith \& Torstensson 1997; Stanko 1990).

The available research also suggests that age has an important influence on fear, as older people are often found to fear crime at higher levels than younger people, although some question the age-fear association (LaGrange and Ferraro 1989; Warr, 1990). In terms of income and race, research suggests that low income individuals are more likely to report fear of crime than middle to upper income individuals. Although this finding is intriguing, little work has considered this variable in much detail (Hale 1996; Vacha and McLaughlin 2004). The connection between a person's race and fear of crime is also inconsistent, with some studies finding white individuals with higher fear of crime levels, and other studies finding non-white individuals with higher fear of crime levels (Lane \& Meeker, 2003; May \& Dunaway 2000; Parker, McMorris, Smith, \& Murty 1993). This issue is further complicated by the fact that the racial composition of the neighborhood in which individuals reside may be more influential than the individual's race in determining fear of crime level (Hale 1996).

Since September 11, 2001, the media coverage of terrorist threats and terrorist groups has increased dramatically and researchers have studied the impact of media exposure on terrorism fear and perceptions (Nellis 2007; Nellis 2009; Lane, Meeker, \& Nellis 2009). DiMaggio (2008) claims that citizen fears are often driven by media framing of issues; when the media has a vested interest in an issue (e.g., terrorism), the reporting of that issue often becomes slanted so that the factual information is reported through a lens of fear and anxiety. Thus, the constant media attention to terrorism, its causes, and its consequences may undermine the larger social order by impacting psychological processes of citizens in the countries where terrorism is reported as a threat (Fisher, Greitemeyer, Kastenmuller, Frey, \& Oßwald 2007) and may inflate the public's fear of terrorism and perceived risk of future attacks (Nellis 2009). 
Demographic predictors of crime fear can serve as a template for exploring correlates of terrorism fear and perceived risk. Extant research findings suggest that females, older persons, nonwhites, and those with a lower household income are more fearful of criminal victimization. As such, we expect that they will be more fearful of terrorism as well. Although not reviewed here, the literature suggests that these variables should also impact risk of terrorism in much the same way. In the following pages we explore whether those predictors of fear and risk of criminal victimization in general apply to fear and risk of terrorism as well.

\section{Predictors of Perceived Risk of Victimization}

Ferraro (1995) was one of the first fear of crime researchers to distinguish fear of criminal victimization from risk of criminal victimization. Ferraro (1995) argued that perceived risk of victimization differed from fear of crime because perceived risk involved a cognitive judgment while fear of crime represented an emotional response. Since that time, most fear of crime researchers now view perceived risk as a cognitive assessment of their actual risk of criminal victimization that is usually the best predictor of fear of criminal victimization. A number of researchers now argue that both risk and fear should be considered in any attempt to understand fear of crime (see Rader, May, and Goodrum 2007, for review).

Several studies have considered the demographic predictors of perceived risk. The relationship between demographic variables and perceived risk does not appear to be as clear as demographic predictors of fear of crime. Although relatively few studies have considered demographic predictors of risk, among those that have, a number find that perceptions of risk is crime-specific and that the relationship between gender, perceived risk, and fear of crime is gender-specific; men have higher levels of perceived risk for robbery than women but women's perceptions of risk impacted fear of sexual assault and burglary (Rader et al. 2007). Relationships between age, income, race, and perceptions of risk of victimization have similar complexities. As such, while there appear to be fairly clear relationships between gender, race, age, income, education, and fear of crime, the relationship between these variables and perceptions of risk of criminal victimization are more complex. As such, more research is needed to clarify these relationships.

\section{Methods}

\section{Sampling}

The data used in this study were derived from a victimization survey of adults in Kentucky conducted in the spring of 2008. In order for the survey to be representative of the state, our initial request was to the Kentucky Division of Motor Vehicle Licensing to obtain a randomly selected list of 5,000 licensed drivers to use 
as the sampling frame for this analysis. In early February, we learned that current technological limitations did not make that a feasible sampling strategy. We then approached the Kentucky State Board of Elections and requested a list of all registered voters in the state of Kentucky. Upon receipt of this list, we selected a random sample of 5,000 registered voters.

Data Collection: In March, 2008, we mailed a postcard to the 5,000 addresses that we had randomly selected advising them that they would be receiving a mail questionnaire asking them to share their experience with crime and victimization. Approximately two weeks later, we mailed a packet containing the questionnaire, a cover letter explaining the purpose of the project, and a metered return envelope to each of the 5,000 selected addresses. Approximately two weeks later, we mailed a reminder postcard to all respondents that had not returned a completed questionnaire (or for whom we had not been notified by the post office that their address was incorrect). Two weeks after that, we mailed another packet containing the same contents as the initial packet. The data collection began in late March and continued into late May, 2008.

One in eight (11.9\%) of the addresses selected were undeliverable to the respondent drawn through the random sampling strategy described above. Although we were notified by survivors that five respondents originally selected were deceased, practically all of the 593 respondents for whom the survey was undeliverable were not able to be contacted because the address supplied by the voter registration database was incorrect. Additionally, 15 respondents informed us by sending a letter or the questionnaire that we sent to them that they did not want to participate in the study. Three additional respondents returned a questionnaire that contained only minimal information (e.g., their gender and one or two other completed questions). Completed, usable questionnaires were received from 1,617 respondents. Using a total sample of 4,407 respondents as the valid sample from which the respondents were drawn, the response rate for this study was thus 36.7 percent.

Survey Instrument: Members of the Statistical Analysis Committee met with a Justice Cabinet representative in December, 2007 to begin the development of a survey draft and to establish the data collection technique and the sampling strategy to be used in this effort. Following this meeting, a draft of the survey was presented to the Statistical Analysis Coordinator for the state of Kentucky, who then sought input from a number of constituencies in January and February, 2008. Feedback from these groups was used to revise the survey. The final version of the survey was completed in March, 2008. 
Predictors of Fear and Risk of Terrorism in a Rural State - May, Herbert, Cline and Nellis

Table 1 Comparison of Sample and Population Demographic Characteristics*

\begin{tabular}{|c|c|c|}
\hline Demographic Variable & $\begin{array}{c}\text { Sample } \\
\text { Frequency (Percent) }\end{array}$ & $\begin{array}{l}2000 \text { Census Estimates } \\
\text { Frequency (Percent) }\end{array}$ \\
\hline \multicolumn{3}{|l|}{ Gender } \\
\hline Male & $730(45.1)$ & $1,975,368(48.9)$ \\
\hline Female & $884(54.7)$ & $2,066,401(51.1)$ \\
\hline Missing Data & $3(0.2)$ & -- \\
\hline \multicolumn{3}{|l|}{ Race } \\
\hline White & $1524(94.2)$ & $3,678,740(91.0)$ \\
\hline Black & $58(3.6)$ & $311,000(7.7)$ \\
\hline Other & $38(2.3)$ & $96,581(2.4)$ \\
\hline Missing Data & $7(0.4)$ & -- \\
\hline \multicolumn{3}{|l|}{ Education } \\
\hline Less than 12 years & $119(7.3)$ & $685,000(25.9)$ \\
\hline G.E.D./High School Graduate & $596(36.9)$ & $888,277(33.6)$ \\
\hline Some College & $300(18.6)$ & $619,651(23.4)$ \\
\hline College Graduate & $406(25.1)$ & $271,418(10.3)$ \\
\hline Postgraduate Work & $152(9.3)$ & $182,051(6.9)$ \\
\hline Missing Data & $44(2.7)$ & -- \\
\hline Age & $\mathrm{N}(\%)$ & \\
\hline $18-24$ & $83(5.1)$ & $401,858(13.4)$ \\
\hline $25-35$ & $192(12.1)$ & $632,494(21.0)$ \\
\hline $36-45$ & $264(16.4)$ & $637,074(21.2)$ \\
\hline $46-55$ & $355(22.0)$ & $539,033.2(17.9)$ \\
\hline $56-65$ & $369(23.0)$ & $361,716.4(12.0)$ \\
\hline 66 and over & $335(20.0)$ & $432,219.4(14.4)$ \\
\hline Missing Data & $14(0.9)$ & -- \\
\hline \multicolumn{3}{|l|}{ Marital Status } \\
\hline Married & $1059(65.5)$ & $1,844,628(57.3)$ \\
\hline Widowed & $103(6.4)$ & $231,630(7.2)$ \\
\hline Divorced & $165(10.2)$ & $353,637(11.0)$ \\
\hline Single, Never Married & $208(12.9)$ & $730,035(22.7)$ \\
\hline Opposite Sex partner sharing a home & $60(3.7)$ & -- \\
\hline Same Sex partner sharing a home & $5(0.3)$ & -- \\
\hline Missing Data & $17(1.1)$ & -- \\
\hline \multicolumn{3}{|l|}{$\begin{array}{l}\text { Number of children }<18 \text { living at current } \\
\text { residence }\end{array}$} \\
\hline 0 & $1047(64.7)$ & -- \\
\hline $1-2$ & $426(26.4)$ & -- \\
\hline 3 or more & $78(4.9)$ & -- \\
\hline Missing Data & $66(4.1)$ & -- \\
\hline
\end{tabular}


Table 1 continued: Comparison of Sample and Population Demographic Characteristics*

\begin{tabular}{|c|c|c|}
\hline Demographic Variable & $\begin{array}{c}\text { Sample } \\
\text { (Frequency \& Percent) }\end{array}$ & $\begin{array}{c}\text { 2000 Census Estimates } \\
\text { (Frequency \& Percent) }\end{array}$ \\
\hline Income & & \\
\hline Less than $\$ 20,000$ & $258(16.0)$ & $477,186(30.0)$ \\
\hline$\$ 20,000$ to less than $\$ 50,000$ & $446(27.6)$ & $604,145(38.0)$ \\
\hline$\$ 50,000$ to less than $\$ 80,000$ & $370(22.9)$ & $274,530(17.2)^{\mathrm{a}}$ \\
\hline$\$ 80,000$ or more & $340(22.3)$ & $235,878(14.8)$ \\
\hline Missing Data & $183(11.3)$ & -- \\
\hline Place of Residence & & $954,116(23.6)$ \\
\hline Urban (Louisville or Lexington) & $390(24.1)$ & $3,087,653(76.4)$ \\
\hline Rural (Rest of State) & $1222(75.6)$ & \\
\hline Missing Data & $5(.3)$ & \\
\hline
\end{tabular}

${ }^{\mathrm{a}}$ Census data are categorized from $\$ 50,000-\$ 75,000$ and over $\$ 75,000$, rather than $\$ 50,000-\$ 80,000$ and over $\$ 80,000$, as the question measuring household income was worded on the survey instrument for this study.

* Due to the differences in the manner in which some of the demographic data were categorized, some of the categorical data were interpolated.

The demographic characteristics of the respondents are presented in Table 1 alongside the state's applicable demographic characteristics, according to the 2000 census. A comparison of the results indicates that respondents in this study were slightly more likely to be female, white, older, married, and have higher levels of income and education than the Census figures indicated for the state of Kentucky. Most of these differences are likely due to the fact that the sample utilized in this study was adults who had registered to vote (rather than a more representative sample like the one that we would have drawn had we had access to the motor vehicle registration database). As such, the results presented here are not truly representative of the population of Kentucky adults. Consequently, given the fact that crime victims are disproportionately male, nonwhite, unmarried, less educated, and with lower household incomes, the results presented here provide at best a conservative estimate of victimization experiences with crime in Kentucky.

\section{Dependent Variables}

Perceived risk of victimization by terrorist activity: Two items were used to create an index to represent risk of victimization by terrorism (the Risk of Terrorism index). Respondents were asked to indicate the likelihood (on a scale of 1 to 10) of the following statements: (1) There will be a terrorist attack in Kentucky during the next 12 months; and (2) There will be a terrorist attack in my community in the next 
12 months. Responses were summed so that the risk of terrorism scale scores ranged from 2 to $20($ Mean $=5.50$, s.d. $=4.09)$. Cronbach's alpha for the index was .830 .

Fear of terrorism: The index representing fear of terrorism (fear of terrorism index) was created by asking respondents to indicate their level of agreement ( 1 =Strongly disagree; $2=$ Somewhat disagree; $3=$ Somewhat agree; $4=$ Strongly agree) with four statements. These statements were as follows: (1) I am afraid I will be a victim in a terrorist attack (26\% agreed); (2) I am afraid someone in my family will be a victim in a terrorist attack (37\% agreed); (3) I am afraid someone in my community will be a victim in a terrorist attack (38\% agreed); and (4) I am afraid someone in Kentucky will be a victim in a terrorist attack (58.8\% agreed). Scores on the index ranged from 4 to 16 (Mean=8.99; s.d.=3.09). Cronbach's alpha for the index was .887.

Table 2 Descriptive Statistics for Fear and Risk of Terrorism Variables

\begin{tabular}{|l|c|c|c|c|}
\hline \multicolumn{1}{|c|}{ Variable } & $\begin{array}{c}\text { Strongly } \\
\text { Agree } \\
\mathbf{N}(\%)\end{array}$ & $\begin{array}{c}\text { Somewhat } \\
\text { Agree } \\
\mathbf{N}(\%)\end{array}$ & $\begin{array}{c}\text { Somewhat } \\
\text { Disagree } \\
\text { N (\%) }\end{array}$ & $\begin{array}{c}\text { Strongly } \\
\text { Disagree } \\
\text { N (\%) }\end{array}$ \\
\hline $\begin{array}{l}\text { I am afraid I will be a victim in a terrorist } \\
\text { attack }\end{array}$ & $66(4.0)$ & $336(20.6)$ & $639(39.1)$ & $526(32.2)$ \\
\hline $\begin{array}{l}\text { I am afraid someone in my family will be a } \\
\text { victim in a terrorist attack }\end{array}$ & $132(8.1)$ & $443(27.1)$ & $579(35.4)$ & $413(25.3)$ \\
\hline $\begin{array}{l}\text { I am afraid someone in my community will } \\
\text { be a victim in a terrorist attack }\end{array}$ & $110(6.7)$ & $480(29.4)$ & $588(36.0)$ & $388(23.7)$ \\
\hline $\begin{array}{l}\text { I am afraid someone in Kentucky will be a } \\
\text { victim in a terrorist attack }\end{array}$ & $269(16.5)$ & $682(41.7)$ & $398(24.3)$ & $216(13.2)$ \\
\hline & Minimum & Maximum & Mean & S.D. \\
\hline $\begin{array}{l}\text { How likely do you think it is that there will } \\
\text { be a terrorist attack in my community during } \\
\text { the next 12 months? }\end{array}$ & 1 & 10 & 2.28 & 2.12 \\
\hline $\begin{array}{l}\text { How likely do you think it is that there will } \\
\text { be a terrorist attack in Kentucky during the } \\
\text { next 12 months? }\end{array}$ & 1 & 10 & 3.22 & 2.30 \\
\hline
\end{tabular}

As the results presented in Table 2 indicate, more respondents were fearful that their family and their community would be victimized by terrorism than were fearful for their own safety from terrorism. Three in five respondents were fearful that 
someone would be a victim of terrorism in Kentucky, indicating that a large number of respondents fear terrorism in their home state seven years after the terrorist events of September 11. Additionally, based on the average response for the perceived risk of terrorism measures, respondents felt relatively little risk of terroristic activity in both their community and in Kentucky. Nevertheless, respondents were more likely to perceive that there would be a terrorist action in the state of Kentucky than in their own community.

\section{Multivariate Results}

Because the purpose of this study was to examine the predictors of both fear of local terrorism and risk of victimization by terrorists in the local community, multivariate linear regression was used to determine what demographic predictors had significant associations with both perceived risk of terrorism victimization and fear of terrorism.

The results of regressing risk of terrorism victimization on the demographic variables are presented in Table 3 on the next page. The results presented in Table 3 suggest that only age, gender, and place of residence impact perceptions of risk of terrorism, as older respondents, female respondents, and those respondents living outside of the large urban areas were significantly more likely to perceive that they would be victimized by terrorist activity than their younger, male, and urban counterparts. Neither race, whether the respondents had children, marital status, or income had an association with risk of terrorism. Additionally, the variables included in the model explained only two percent of the variation in perceived risk among the respondents.

The results of regressing fear of terrorism on the demographic variables and perceptions of risk of terrorism are presented in Table 4 (next page). The results presented in Table 4 suggest that gender, marital status, and perceived risk of terrorism all had a significant impact on fear of terrorism, as females, married respondents, and those with highest levels of perceived risk of terrorism were all significantly more fearful of terrorism than their counterparts with lower levels of risk of terrorism and their male and unmarried counterparts. The variables included in the model explained only 16 percent of the variation in perceived risk among the respondents.

\section{Discussion}

Using data from over 1,600 Kentucky adults, in this study we attempted to identify demographic predictors of both perceived risk of terrorism and fear of terrorism victimization. In doing so, we hoped to expand a largely nonexistent 
Predictors of Fear and Risk of Terrorism in a Rural State - May, Herbert, Cline and Nellis

Table 3 Multivariate Linear Regression Results of Regressing Perceived Risk of Terrorism on Demographic Variables

\begin{tabular}{|c|c|c|c|c|c|}
\hline & $\mathrm{B}$ & Std. Error & Beta & $\mathrm{t}$ & Sig. \\
\hline (Constant) & 4.660 & .691 & & 6.749 & .000 \\
White & -.457 & .486 & -.026 & -.941 & .347 \\
Age & $\mathbf{. 0 1 7}$ & $\mathbf{. 0 0 8}$ & $\mathbf{. 0 6 7}$ & $\mathbf{2 . 1 4 9}$ & $\mathbf{. 0 3 2}$ \\
Female & $\mathbf{. 6 5 5}$ & $\mathbf{. 2 1 8}$ & $\mathbf{. 0 8 2}$ & $\mathbf{2 . 9 9 9}$ & $\mathbf{. 0 0 3}$ \\
Respondent has kids & .256 & .263 & .030 & .973 & .331 \\
Married & .117 & .256 & .014 & .457 & .648 \\
Income & .085 & .238 & .011 & .359 & .720 \\
Rural & $\mathbf{. 8 2 1}$ & $\mathbf{. 2 5 7}$ & $\mathbf{. 0 8 8}$ & $\mathbf{3 . 1 9 2}$ & $\mathbf{. 0 0 1}$ \\
\hline
\end{tabular}

$F=3.47 ; p<.001 ; R$ Square $=.018 ;$ Df: 1354

Table 4 Multivariate Linear Regression Results of Regressing Fear of Terrorism on Perceived Risk of Terrorism and Demographic Variables

\begin{tabular}{|c|c|c|c|c|c|}
\hline & $\mathrm{B}$ & Std. Error & Beta & $\mathrm{t}$ & Sig. \\
\hline (Constant) & 5.856 & .499 & & 11.731 & .000 \\
White & .526 & .347 & .039 & 1.515 & .130 \\
Age & .007 & .006 & .038 & 1.333 & .183 \\
Female &. $\mathbf{4 2 4}$ & $\mathbf{. 1 5 6}$ & $\mathbf{. 0 6 9}$ & $\mathbf{2 . 7 1 8}$ & $\mathbf{. 0 0 7}$ \\
Respondent has kids & .012 & .187 & .002 & .067 & .947 \\
Married & $\mathbf{. 5 9 7}$ & $\mathbf{. 1 8 3}$ & $\mathbf{. 0 9 2}$ & $\mathbf{3 . 2 6 8}$ & $\mathbf{. 0 0 1}$ \\
Income & .150 & .169 & .024 & .889 & .374 \\
Rural & .332 & .184 & .046 & 1.804 & .071 \\
Perceived Risk of & $\mathbf{. 2 8 9}$ & $\mathbf{. 0 2 0}$ & $\mathbf{. 3 7 3}$ & $\mathbf{1 4 . 8 1 0}$ & $\mathbf{. 0 0 0}$ \\
Terrorism & & & & & \\
\hline
\end{tabular}

$F=33.49 ; p<.001 ; R$ Square $=.167 ;$ Df: 1347 
literature regarding perceptions of risk of terrorism and fear of terrorism victimization. Our findings from that effort are discussed in detail below.

First and foremost, the demographic variables included in the model to explain perceived risk of terrorism have minimal impact on that variable. Although females, rural respondents, and older respondents were more likely to have elevated levels of perceived risk of terrorism, the demographic variables included in the model explained only two percent of the variation in perceived risk of terrorism among the respondents in this study. Consequently, it is evident that perceptions of risk of terrorism are not explained by demographic variables normally associated with perceived risk of other types of crimes. Thus, perceptions of risk of terrorism must be explained by contextual or theoretical factors rather than demographic factors.

Given the global nature of the questionnaire used to collect data for this study, we were unable to explore in great detail a number of these factors that may impact risk of terrorism victimization. Because the questions included in the risk measure were geographic in nature (e.g., risk of terrorism in the respondent's community and risk of terrorism in the state where they lived, Kentucky), demographic characteristics are probably not as important in predicting risk of terrorism as characteristics of where the respondent lives. Interestingly, residents of areas outside of Lexington and Louisville (the two large metropolitan areas in Kentucky) had higher levels of perceived risk of terrorism than their counterparts in those two cities. This finding may be due to the unique nature of Kentucky, as most of the targets considered to be at greatest risk of terrorist activity in Kentucky (e.g., Bluegrass Army Depot, Fort Campbell, Fort Knox, most of the Interstate system) are in rural areas. As such, respondents living in Louisville and Lexington may be correct in considering themselves less at risk of terrorism than their more rural counterparts. Future research efforts exploring perceptions of risk of terrorism should include questions to identify whether respondents have a terrorist target in their community to determine if this relationship is truly the best explanation of levels of perceived risk of terrorism.

A second important finding from this research has to do with the relationship between perceived risk of terrorism victimization and fear of terrorism victimizations. Although the demographic variables did little to predict either risk or fear of terrorism, perceived risk of terrorism was a strong predictor of fear of terrorism; in other words, those respondents who considered themselves most at risk of terrorism in their community and state were also most likely to fear terrorism victimization in their family and community. This relationship mirrors that found in the research regarding fear of more traditional crimes and provides insight into methods to reduce fear of terrorism (discussed below). 
A third important finding from this research has to do with the impact of gender on both perceived risk of terrorism and fear of terrorism. Women were significantly more likely to perceive themselves at risk of terrorism and to fear terrorism as well. As such, gender is an important predictor of fear of terrorism, just as it is an important predictor of fear of more traditional crimes as well. This finding is particularly interesting because the relationship between gender and fear of crime is often attributed to the "shadow of sexual assault" hypothesis that suggests that fear of all crime is colored by fear of sexual assault among females (Ferraro 1995; Warr 1984). Given that the measures used to estimate fear of crime are geography based rather than crime-specific (e.g., afraid of a terrorist activity in my community v. afraid of being robbed), the shadow of sexual assault is probably not associated with fear of terrorism in the same manner as fear of more traditional crimes.

Given this fact, the fact that females are more fearful than males of terrorism among their family and in their community, the evidence presented here suggests that the best explanation of the gender-fear paradox discussed earlier may be that women's fear of crime and men's lack of fear is part of the gender socialization process. In other words, women are socialized to be more open about their emotions and thus women are more likely than men to admit their fears, even on confidential, self-report surveys. It may also be that women are reacting to their own reality in which they are more likely to be the victims of violence by immediate family members, especially their partners. Future research efforts should continue to explore this phenomenon by comparing place-based fear with crime-based fear among the same sample of respondents. By doing so, researchers may eventually understand the gender-fear paradox in ways that current knowledge does not allow.

A final important finding from this research has to do with the extent of fear of terrorism victimization among the respondents in this sample. The findings presented here suggest that, if the respondents in this sample are indicative of the larger population, concerns about fear of terrorism increase as an individual considers terroristic activity outside of the environment they can control. As the results in Table 2 suggest, only one in four respondents agreed that they were afraid they would personally be a victim in a terrorist action. However, one in three was afraid someone in their family and or their community would be a victim in a terrorist action and almost three in five were afraid someone in Kentucky would be victimized by terrorism. As such, it appears that people may not be as concerned about their personal victimization by terrorism as they are about their family, community, and state. Alternatively, it may also be the case that the respondents were making a somewhat logical, cognitive judgment in that answer. Individuals may realize that they personally have little chance of terrorism victimization and thus have lower levels of fear of terrorism when asked about their own victimization but realize that, 
as the size of the population at risk increases, the likelihood of terrorism victimization increases as well. Thus, the respondent may realize their chance of personal victimization is less than that of their family, community, and state populations based on the sheer increase in numbers in those populations. Future research efforts should build on this finding by including more specific measures of fear and risk of terrorism victimization with these somewhat general measures to attempt to better understand these findings.

\section{Conclusion}

While we feel this study has made a number of substantive contributions to the area of fear and perceptions of risk of terrorism victimization, we are aware that there are a number of limitations that reduce its generalizability. As mentioned earlier, the first limitation has to do with the sampling frame of this report. Our initial plan was to obtain 5,000 addresses from the Kentucky Division of Motor Vehicle Licensing. Nevertheless, current system limitations would not allow us to draw a sample of that size that was representative of drivers throughout the state. Because that sample was not available, we then had to use the next most representative set of addresses that we could find: voter registration records. Because voters rarely update their registration records when they move across town, however, use of these records uncovered almost 600 (593) addresses at which the survey was undeliverable. This further limited the potential number of respondents as well.

Additionally, because we were only able to use a sample of registered voters, that sampling strategy necessarily excludes one group of adults: unregistered voters. A number of researchers have determined that residents who are young, mobile, less educated, and of lower socioeconomic status are less likely to both register to vote and vote than their counterparts (see Knack, \& White 2000, for review).

Additionally, in Kentucky, registered voters are more likely to be female (53\% of registered voters) and Democrat (57\% of registered voters-- see Kentucky State Board of Election statistics available at http://www.elect.ky.gov/stats/). As such, a random sample of registered voters in Kentucky is likely to be slightly older, less mobile, more educated, of higher socioeconomic status, slightly more female, and more likely to be Democrats. The demographic statistics presented in Table 1 suggest that these characteristics are evident in this sample as well.

Another limitation has to do with the type of measures used in this study. As we pointed out previously, to fully understand fear and risk of terrorism victimization and its causes and consequences, a number of measures specifically examining those phenomena need to be included. Given the global nature of the survey from which we drew our data, we were not able to go to the level of detail necessary to fully understand these relationships. 
Nevertheless, within the limitations of this sample, we feel that the findings presented here are informational and relevant and should be considered by those working in any function that deals with terrorism and its consequences. The research presented here suggests that there are important steps policymakers and professionals working in law enforcement and homeland security can take to reduce both fear and risk of terrorism victimization. The most important of these steps is to educate American citizens about the reality of terrorism victimization.

Between 2002 and 2011, the Department of Homeland Security (DHS) used a five level, color-coded scale of terrorism threat levels to attempt to help educate citizens about their risk of terrorism. After almost a decade, DHS realized the system was not meeting the goal of providing citizens a realistic assessment of their terror risk (in virtually all circumstances, the national threat level was yellow (elevated, significant risk of terrorist attack) and replaced that system with the National Terrorism Advisory System (available at http://www.dhs.gov/ynews/releases/pr 1303296515462.shtm).

Because these levels remained relatively unchanged between 2002 and 2011, most citizens ignored them because they felt they were meaningless or there was little they could do in their daily lives to increase or decrease their chances of terrorism victimization. While this is probably true to some extent (and probably more for terrorism than more traditional crimes), this is certainly not always the case.

To combat this problem, local emergency management and criminal justice agencies should provide more detailed information to the residents of their community regarding the threat levels of terrorism in that community. Because the evidence presented here suggests that individuals are more fearful of terrorism as the population at risk increases, then having good, current information about the terrorism threat level in their own community will make individuals feel safer from terrorist activity in their homes and communities where the vast majority of their activities take place. While we do not know for certain in every community and every situation, intuitively, a resident of a rural Kentucky community with no strategic governmental assets is probably at far less risk of terrorist activity than a Kentucky resident living near a strategic governmental asset. This knowledge should make residents in those communities realize that they are at less risk of terrorism victimization and thus less fearful of terrorism in general. Until such a strategy is considered and implemented, fear of terrorism is likely to present a threat for all. 


\section{References}

Borgeson, K. \& Valeri, R. 2009. Terrorism in America. Jones and Bartlett Publishers, LLC, Sudbury, MA.

Boscarino, J.A., Figley, C.R., \& Adams, R.E. 2003. Fear of terrorism in New York after the September 11 terrorist attacks: Implications for emergency mental health and preparedness. Emergency Mental Health, 199-209. Retrieved from www.fsu.edu on 02/15/09.

Carlson, D.K. 2004. Terrorism Fears not Partisan; War's Progress Is. Washington D.C.: Gallup. Retrieved March 13, 2009 from http://www.gallup.com/poll/12787/Terrorism-Fears-Partisan-WarsProgress.aspx.

Carroll, J. 2009. Terrorism. Washington D.C.: Gallup. Retrieved March 14, 2009 from http://www.gallup.com/poll/10009/Terrorism.aspx

Dimaggio, A.R. 2008. MassMedia, Mass Propaganda: Examining American News in the 'War on Terror.' Lanham, MD: Lexington Books.

Ferraro, K., \& LaGrange, R. 1987. The measurement of fear of crime. Sociological Inquiry 57, 70-101.

Ferraro, K. 1995. Fear of Crime: Interpreting Victimization Risk. Albany, NY: State University of New York Press.

Ferraro, K. 1996. Women's fear of victimization: Shadow of sexual assault. Social Forces, 75, 667-690.

Fischer, P., Greitemeyer, T., Kastenmuller, A., Frey, D., \& Oßwald, S. 2007. Terror salience and punishment: Does terror salience induce threat to social order? Journal of Experimental Social Psychology, 43, 964-971.

Fisher, B.S., \& Sloan, J.J. III. 2003. Unraveling the fear of sexual victimization among college women: Is the 'shadow of sexual assault' hypothesis supported? Justice Quarterly, 20, 633-659.

Friedman, L.S. 2005. Terrorism. Farmington Hills, MI: Thompson Gale.

Gilchrist, E., Bannister, J., Ditton, J., \& Farrall, S. 1998. Women and the fear of crime: Challenging the accepted stereotype. British Journal of Criminology, 38, 283-98. 
Predictors of Fear and Risk of Terrorism in a Rural State - May, Herbert, Cline and Nellis

Goodey, J. 1997. Boys don't cry: Masculinities, fear of crime and fearlessness. British Journal of Criminology, 37, 401-418.

Hale, C. 1996. Fear of crime: A review of the literature. International Review of Victimology, 4, 79-150.

Haynie, D.L. 1998. The gender gap in fear of crime, 1973-1994: A methodological approach. Criminal Justice Review, 23, 29-50.

Hirschkorn, P. 2007. New York Reduces 9/11 Death Toll by 40. New York: Cable News Network New York Bureau. Retrieved 3/13/09 from http://www.cnn.com/2003/US/Northeast/10/29/wtc.deaths/

Josiger, W.J. 2009. Fear factor: The impact of terrorism on public opinion. Paper presented at the annual meeting of the International Sociological Association's Annual meetings, New York, NY.

Killias, M., \& Clerici, C. 2000. Different measures of vulnerability in their relation to different dimensions of fear and crime. British Journal of Criminology, 40, 437-450.

Knack, S., \& White, J. 2000. Election-day registration and turnout inequality. Political Behavior, 22, 29-44.

LaGrange, R.L., \& Ferraro, K.F. 1989. Assessing age and gender differences in perceived risk and fear of crime. Criminology, 27, 697-719.

Lane, J., \& Meeker, J.W. 2003. Social disorganization perceptions, fear of gang crime, and behavioral precautions among Whites, Latinos, and Vietnamese. Journal of Criminal Justice, 32, 49-63.

Lane, J., Meeker, J.W., \& Nellis, A. 2009. Perceived risk and fear of terrorism and willingness to lose personal rights. Paper presented at the American Society of Criminology Annual Meeting, Philadelphia, PA, November 6, 2009.

May, D.C. 1999. Scared kids, unattached kids, or peer pressure: Why do students carry firearms to school? Youth and Society, 31, 100-127.

May, D.C. 2001a. Adolescent Fear of Crime, Perceptions of Risk, and Defensive Behaviors: An Alternative Explanation of Violent Delinquency. Lewiston, NY: Edwin Mellen Press.

May, D.C. 2001b. The effect of fear of sexual victimization on adolescent fear of crime. Sociological Spectrum, 21, 141-174. 
May, D.C., \& Dunaway, R.G. 2000. Predictors of fear of criminal victimization at school among adolescents. Sociological Spectrum, 20, 149-168.

Mesch, G.S. 2000. Perceptions of risk, lifestyle activities, and fear of crime. Deviant Behavior, 21, 47-62.

Moore, D.E. 1999. Fear of Terrorism Affects Many American's Plans for New Year Celebration. Washington D.C.: Gallup. Retrieved March 14, 2009 from http://www.gallup.com/poll/3379/Fear-Terrorism-Affects-Many-AmericansPlans-New-Year-Celebration.aspx

National Victim Assistance Academy. 2002. National Victim Assistance Academy Textbook-Chapter 2:9- Terrorism and Victim Assistance Issues. Retrieved March 23, 2009 from http://www.ojp.usdoj.gov/ovc/assist/nvaa2002/chapter22_9.html.

Nellis, A. 2007. How does the American public cope with terrorism-related information? Unpublished doctoral dissertation. American University: Washington, D.C.

Nellis, A. 2008. Fear of terrorism. In Kevin Borgeson (ed.) Domestic Terrorism (2008). Boston: Jones and Bartlett Press.

Nellis, A. 2009. Gender differences in fear of terrorism. Journal of Contemporary Criminal Justice 25, 322-340.

Parker, K.D., McMorris, B.J., Smith, E., \& Murty, K.S. 1993. Fear of crime and the likelihood of victimization: A bi-ethnic comparison. The Journal of Social Psychology, 133, 723-732.

Rader, N.E., May, D.C., \& Goodrum, S. 2007. An empirical assessment of the 'threat of victimization:' Considering fear of crime, perceived risk, avoidance, and defensive behaviors. Sociological Spectrum, 27, 475-505.

Saad, L. 2004. Three Years after 9/11, Most Americans Carrying on Normally. Washington D.C.: Gallup. Retrieved March 14, 2009 from http://www.gallup.com/poll/12991/Three-Years-After-911-Most-AmericansCarrying-Normally.aspx

Schafer, J.A., Huebner, B., Bynum, T.S. 2006. Fear of crime and criminal victimization: Gender-based contrasts. Journal of Criminal Justice, 34, 285 301. 
Smith, B. 2008. A Look at Terrorist Behavior: How They Prepare, Where They Strike. NIJ Journal, 2-6.

Smith, W.R., \& Torstensson, M. 1997. Gender differences in risk perception and neutralizing fear of crime. British Journal of Criminology, 37, 608-634.

Stanko, E.A. 1990. Everyday Violence. London: Pandora Press.

Stern, J. 2004. Fearing evil. Social Research, 71, 1111-1126.

Vasilenko, V.I. 2004. The concept and typology of terrorism. Statutes and Decisions, 40, 46-56.

Victor S, J. 2006. Why the terrorism scare is a moral panic. The Humanist, 66, 9-12.

Warr, M. 1984. Fear of victimization: Why are women and the elderly more afraid? Social Science Quarterly, 65, 681-702.

Warr, M. 1990. Dangerous situations: Social context and fear of victimization. Social Forces, 68, 891-907.

Warr, M., \& Ellison, C. 2000. Rethinking social reactions to crime: Personal and altruistic fear in family households. American Journal of Sociology, 106(3), 551-578.

Warr, M., \& Stafford, M. 1983. Fear of victimization: A look at the proximate causes. Social Forces, 61, 1033-1043.

Wilcox, P., May, D.C., \& Roberts, S.D. 2006. Student weapon possession and the 'fear of victimization hypothesis;' Unraveling the temporal order. Justice Quarterly, 23, 502-529. 